\title{
Peningkatan Motilitas Spermatozoa Kauda Epididimis Sapi Bali di Rumah Potong Hewan (RPH) Kota Ternate Menggunakan Kafein
}

\author{
Improvement Of Spermatozoa Motility Of Cauda Epididymis Bali Cattle in \\ Slaughterhouses of Ternate City Using Caffeine
}

\author{
Oktora Dwi Putranti ${ }^{1)}$ dan Zulaeha Mabud ${ }^{2)}$ \\ 1)Fakultas Pertanian, Prodi Peternakan. Universitas Khairun. Ternate. \\ ${ }^{2)}$ Fakultas Teknik, Prodi Teknik Elektro. Universitas Khairun. Ternate \\ e-mail: oktora@unkhair.ac.id
}

Sejarah artikel : Menerima : 08 Oktober 2019 Revisi : 22 Oktober 2019 Diterima : 23 Desember 2019 Online : 31 Desember 2019

\begin{abstract}
ABSTRAK
Penelitian "Peningkatan Motilitas Spermatozoa Kauda Epididimis Sapi Bali di Rumah Potong Hewan (RPH) Kota Ternate Menggunakan Kafein", bertujuan untuk mengkaji pengaruh penambahan kafein terhadap motilitas spermatozoa kauda epididimis sapi Bali dan mengukur berapa jumlah penambahan kafein yang dapat meningkatkan motilitas spermatozoa kauda epididimis sapi Bali. Koleksi testes diambil dari Rumah Potong Hewan (RPH) Kota Ternate, proses analisis sperma dilakukan di laboratorium Bioteknologi Universitas Khairun. Metode penelitian ini adalah sperma kauda epididimis dimasukkan dalam pengencer tris kuning telur kemudian diberi perlakuan penambahan kafein T0 $(0 \mathrm{mg} / \mathrm{ml})$, T2 $(2 \mathrm{mg} / \mathrm{ml})$, T4 (4 mg/ml), dan T6 (6 mg/ml) dengan 4 kali ulangan. Parameter dianalisis adalah kualitas sperma secara makroskopis dan mikroskopis. Data yang diperoleh dianalisis dengan analisis variance (ANOVA) satu arah, apabila terdapat perbedaan yang nyata $(P \leq 0,05)$ atau sangat nyata $(P \leq 0,01)$, dilanjutkan uji Tukey-W-Procedure dengan SPSS 18. Hasil penelitian menunjukkan bahwa penambahan kafein 2-4 $\mathrm{mg} / \mathrm{ml}$ pada pengencer tris kuning telur sperma kauda epididymis sapi Bali mampu meningkatkan motilitas sperma.
\end{abstract}

Kata kunci : kauda epididimis, sapi Bali, kafein, motilitas

\begin{abstract}
Research on "Increasing Motility of Spermatozoa of cauda Epididymis of Bali Cattle in Slaughterhouses of Ternate City Using Caffeine", aims to examine the effect of the addition of caffeine on the motility of the spermatozoa of the Bali cow epididymis and measure how much the addition of caffeine can increase the motility of the Bali cow epididymis spermatozoa motility. Testes collection was taken from the Slaughterhouse (RPH) Ternate City, sperm analysis process was carried out in the Biotechnology Laboratory of Khairun University. The method of this research is the cauda epididymis sperm is inserted into the egg yolk thinner then given the addition of caffeine treatment T0 $(0 \mathrm{mg} / \mathrm{ml})$, T2 $(2 \mathrm{mg} / \mathrm{ml})$, T4 $(4 \mathrm{mg} / \mathrm{ml})$, and T6 $(6 \mathrm{mg} / \mathrm{ml})$ with 4 replications. The parameters analyzed were the quality of sperm macroscopically and microscopically. The data obtained were analyzed by one-way analysis of variance $(A N O V A)$, if there were significant differences $(P<0.05)$ or very real $(P<0.01)$, followed by the Tukey-W-Procedure test with SPSS 18. The results showed that the addition of caffeine $2-4 \mathrm{mg} / \mathrm{ml}$ to thinner Tris yolk sperm cauda epididymis Bali cattle could increase sperm motility.
\end{abstract}

Keywords : cauda epididymis, Bali cattle, caffeine, motility

\section{PENDAHULUAN}

Rumah potong hewan (RPH) berfungsi menghasilkan daging guna memenuhi kebutuhan protein hewani. Dalam satu hari
RPH kota Ternate mampu memotong sapi sejumlah 10 ekor. Sapi yang dipotong tentu saja memiliki tingkat kesehatan dan performa yang baik. Selain menghasilkan daging RPH juga 
menghasilkan plasma nutfah yaitu spermatozoa. Testis adalah organ reproduksi sapi jantan yang bukan termasuk dalam karkas, sehingga sering tidak diperhatikan. Padahal testis merupakan tempat spermatozoa diproduksi. Jika testis RPH ini tidak dimanfaatkan padahal memiliki manfaat besar dalam upaya peningkatan populasi ternak melalui inseminasi buatan (IB).

Spermatozoa yang telah matang atau dewasa dihasilkan di dalam testis akan disimpan dalam kauda epididimis. Namun spermatozoa kauda epididimis memiliki motilitas yang rendah karena tidak keluar melalui ejakulasi. Untuk meningkatkan motilitas spermatozoa kauda epididimis maka dalam pengecer spermatozoa perlu ditambahkan zat additive yang berfungsi sebagai prekusor.

Kafein adalah alkaloid yang memiliki aksi sebagai stimulant sistem saraf pusat atau central nervous system (CNS) dan metabolisme pada manusia. Penelitian ini dilakukan dengan penambahan kafein dalam pengencer spermatozoa. Peningkatan motilitas sperma dapat terjadi karena kafein mampu menghambat reseptor adenosine, menghambat aktivitas phosphodiesterase, dan pertukaran kalsium intraselluler (Lamarine, 1998). Mekanisme tersebut berpengaruh terhadap perubahan konsentrasi intraselluler siklik adenosine monophosphate (cAMP) untuk motilitas sperma (Gerhastuti, 2009). Dengan mekanisme kerja kafein tersebut diharapkan akan dapat meningkatkan motilitas spermatozoa kauda epididimis.

\section{METODE PENELITIAN}

Waktu dan Tempat

Penelitian ini dilaksanakan dari bulan April sampai September 2019. Koleksi testis dari Rumah Potong Hewan (RPH) Kota Ternate, proses pengenceran dan analisis sperma kauda epididymis sapi Bali dengan penambahan kafein dilakukan di Laboratorium Bioteknologi Universitas Khairun, Ternate.

\section{Alat dan Bahan}

Alat : cawan petri, object glass, cover glass, scapel, blade, gelas ukur, kamar hitung Neubauer, mikropipet, microtip, pinset, $\mathrm{pH}$ meter cool box dan mikroskop.

Bahan: sperma kauda epididimis, $\mathrm{NaCl}$ 0,9\%, eosin nigrosin, streptomisin, penicillin, Tris, Kuning telur, Fruktosa, formol salin, asam citrate, gliserol dan kafein.

Prosedur Penelitian

Koleksi Spermatozoa Kauda Epididimis
Testis dikoleksi dari 12 ekor sapi Bali jantan. Testis yang sudah dibersihkan dari kulitnya kemudian diklem menggunakan tang arteri pada 4 bagian yaitu korpus, kaput, kauda dan vas deferen. Dimasukkan ke dalam cairan $\mathrm{NaCl}$ fisiologis 0,9\% yang telah diberi antibiotik streptomisin 0,1 $\mathrm{g} / \mathrm{l}$ dan penisilin 0,06 $\mathrm{g} / \mathrm{l}$, diletakkan dalam cool box yang berisi air hangat dengan temperatur $37^{\circ} \mathrm{C}$ untuk di bawa ke laboratorium. Kauda epididimis dipisahkan dari testis, sayat jaringan kauda epididimis kemudian hisap menggunakan mikropipet cairan putih pada kauda epididimis letakkan dalam gelas objek dan dianalisis karakteristiknya (Putranti, 2017).

Analisis karakteristik sperma

Karakteristik sperma yang dilihat secara makroskopis dan mikroskopis adalah:

a. $\mathrm{pH}$. Diukur dengan $\mathrm{pH}$ indicator paper. Jaringan kauda epididimis disayat kemudian ditempelkan $\mathrm{pH}$ meter kemudian dilihat perubahan warnanya.

b. Warna. Warna sperma dapat dilihat dengan menyayat jaringan kauda epididimis secara langsung. Semen sapi normal berwarna seperti susu atau krem keputih-putihan dan keruh (Arifiantini, 2012).

c. Motilitas. Penilaian motilitilas sperma dapat dianalisis dengan melihat motilitas gerakan massa. Pergerakan gelombang sperma dari + (tidak ada pergerakan), ++ (gelombang tipis dengan sedikit gerakan progresif) dan +++ (gelombang tebal dengan gerakan progresif) (Toelihere, 1993).

d. Persentase sperma hidup. Teteskan sperma kauda epididimis menggunakan mikropipet dan eosin nigrosin tetes kemudian dicampur dengan perbandingan 1:3, dihomogenkan secara cepat, buat preparat ulas dan dilihat menggunakan mikroskop cahaya. Hitung persentase hidup sperma dan yang mati, dengan sperma yang terwarnai merah menandakan sperma mati dan yang berwarna putih menunjukkan sperma hidup, hitung pada 200 sel sperma (Arifiantini, 2012).

e. Morfologi sperma. Morfologi dapat dilihat menggunakan preparat yang sama dari preparat ulas persentase sperma hidup, dengan menghitung persentase sperma normal dan abnormal dari 200 sel sperma (Arifiantini, 2012).

f. Konsentrasi. Sperma kauda epididimis $1 \mu \mathrm{l}$ dimasukkan dalam formol salin $499 \mu \mathrm{l}(1$ : 500 ), kemudian homogenkan dengan meneteskan dalam couting chamber 8-10 
$\mu$ hitung jumlah sperma yang ada dalam 5 kotak dari 16 kotak kecil (Arifiantini, 2012).

Analisis Motilitas

Spermatozoa yang memiliki nilai makroskopis dan mikroskopis baik dengan motilitas $50 \%$ diproses lebih lanjut yaitu pengenceran Tris kuning telur dan diberi perlakuan dengan penambahan kafein T0 $(0$ $\mathrm{mg} / \mathrm{ml})$, T2 (2 mg/ml), T4 (4 mg/ml) dan T6 (6 $\mathrm{mg} / \mathrm{ml}$ ). Sperma diteteskan dalam gelas objek yang sudah diberi perlakuan Kafein dengan mikropipet $10 \mu \mathrm{l}$, kemudian ditutup dengan cover glass kemudian diamati motilitasnya.

\section{Analisis Data}

Data yang diperoleh dianalisis dengan analisis variance (ANOVA) satu arah, apabila terdapat perbedaan yang nyata $(P \leq 0,05)$ atau sangat nyata $(P \leq 0,01)$, dilanjutkan uji Tukey-WProcedure dengan SPSS 18 (Trihendradi, 2010).

\section{HASIL DAN PEMBAHASAN}

Sampel sperma yang dianalisis dalam penelitian ini adalah sperma segar yang dikoleksi dengan rata-rata nilai makroskopis terlihat pada tabel dibawah ini.

Tabel . Rata-rata nilai makroskopis dan mikroskopis.

\begin{tabular}{ll}
\hline \multicolumn{1}{c}{ Karakteristik } & \multicolumn{1}{c}{ Nilai Rata-rata } \\
\hline $\mathrm{pH}$ & $7,28 \pm 0,15$ \\
Warna & putih susu \\
Konsistensi & Kental \\
Bau & Spesifik \\
Motilitas (\%) & ++ \\
Konsentrasi & $1734 \pm 43,45 \times 10^{6}$ \\
(sperma/ml) & $81,00 \pm 5,90$ \\
Sperma hidup (\%) & $57,30 \pm 6,02$ \\
Sperma normal (\%) & \\
\hline
\end{tabular}

Data: Koleksi sperma segar kauda epididymis sapi Bali

Hasil analisis makroskopis sperma segar kauda epididimis sapi Bali berwarna putih susu dan $\mathrm{pH} 7,18 \pm 0,13$. Hal ini sesuai dengan pernyataan Garner dan Hafez (2000) bahwa warna semen sapi yang normal berwarna putih susu sampai krem kekuningan dengan $\mathrm{pH}$ 6,4-7,8. Hasil evaluasi pemeriksaan mikroskopis diperoleh gerakan massa ++, yang berarti sperma memiliki gelombang massa sedang tetapi cepat berpindah tempat (Arifiantini, 2012) dan layak diproses dalam pembuatan sperma beku karena memiliki gerakan massa ++/+++ (Tambing, 2000). Hasil penelitian ini didapatkan nilai motilitas ++ , konsentrasi $\left(1734 \pm 43,45 \times 10^{6} \mathrm{sperma} / \mathrm{ml}\right)$, persentase hidup $(81,00 \pm 5,90 \%)$ dan morfologi sperma normal $5 \overline{7}, 30+6,02 \%$. Hasil tersebut tidak berbeda jauh dengan sperma ejakulat yang memiliki motilitas 40 $70 \%$, konsentrasi $800-2000 \times 10^{6} \mathrm{sperma} / \mathrm{ml}$, serta morfologi sperma normal $65-95 \%$ (Garner and Hafez, 2000).

\section{Motilitas sperma}

Fertilitas dapat terjadi bila sperma mampu berenang menuju tuba fallopi bertemu dengan sel telur sehingga terjadi penetrasi dalam zona pellusida. Sperma untuk bisa berenang cepat membutuhkan energi, selain dari pengencer dapat diberikan zat additive yaitu kafein sebagai prekusor. Hasil penambahan kafein dalam pengencer tris kuning telur sperma kauda epididymis sapi Bali dapat terlihat pada tabel dibawah ini.

Tabel . Motilitas sperma kauda epididymis dengan perlakuan kafein pada pengencer Tris kuning telur (rerata \pm SD)

\begin{tabular}{lcccc}
\hline \multirow{2}{*}{ Variabel } & \multicolumn{4}{c}{ Perlakuan Kafein } \\
\cline { 2 - 5 } \multicolumn{1}{c}{ T0 } & T2 & T4 & T6 \\
\hline Motilitas $(\%)$ & $23,43 \pm 6,40^{\mathrm{b}}$ & $28,40 \pm 2,20^{\mathrm{a}}$ & $31,00 \pm 0,37^{\mathrm{a}}$ & $23,00 \pm 5,41^{\mathrm{b}}$ \\
VCL $(\mu \mathrm{m} / \mathrm{s})$ & $85,06 \pm 1,40^{\mathrm{b}}$ & $85,10 \pm 4,68^{\mathrm{b}}$ & $88,00 \pm 12,03^{\mathrm{a}}$ & $88,01 \pm 2,40^{\mathrm{a}}$ \\
VAP $(\mu \mathrm{m} / \mathrm{s})$ & $41,00 \pm 3,70^{\mathrm{b}}$ & $46,41 \pm 1,52^{\mathrm{a}}$ & $42,01 \pm 2,21^{\mathrm{b}}$ & $39,22 \pm 5,40^{\mathrm{b}}$ \\
VSL $(\mu \mathrm{m} / \mathrm{s})$ & $29,25 \pm 3,24^{\mathrm{b}}$ & $34,47 \pm 3,23^{\mathrm{a}}$ & $31,02 \pm 1,40^{\mathrm{b}}$ & $29,25 \pm 4,21^{\mathrm{b}}$ \\
\hline
\end{tabular}

Keterangan: superskrip yang sama dalam baris yang sama menunjukkan tidak terdapat perberbeda $(P>0,05)$. T0 $=0 \mathrm{mg} / \mathrm{ml}, \mathrm{T} 2=2 \mathrm{mg} / \mathrm{ml}, \mathrm{T} 4=4 \mathrm{mg} / \mathrm{ml}$, dan T6=6mg $/ \mathrm{ml}$. Curve linier velocity ( $\mathrm{VCL})$, average path velocity (VAP), dan straight line velocity (VSL).

Pergerakan motilitas sperma yang baik adalah bergerak cepat lurus ke depan, sehingga dapat dianalisis 3 variabel kecepatan motilitas yaitu curvelinier linier 
velocity ( $\mathrm{VCL})$, average path velocity (VAP) dan straight line velocity (VSL). VCL adalah kecepatan sperma dalam satu menit lintasan kurva, VAP merupakan kecepatan sperma dalam satu menit lintasan rata-rata alur dan VSL yaitu kecepatan sperma dalam satu menit lintasan lurus (Sarastina dkk, 2014). Hasil Uji Lanjut dengan Tukey memperlihatkan bahwa perlakuan kafein T2 $(28,40 \pm 2,20 \%)$ dan T4 (31,00 $\pm 0,37 \%)$ berbeda nyata $(P>0,05)$ terhadap T0 $(23,43$ $\pm 6,40 \%)$ dan T6 $(23,00 \pm 5,41 \%)$. Hal ini menunjukkan bahwa penambahan kafein 2$4 \mathrm{mg} / \mathrm{ml}$ mampu meningkatkan motilitas spermatozoa dibandingkan tanpa perlakuan $0 \mathrm{mg} / \mathrm{ml}$ begitu juga dengan pemberian 6 $\mathrm{mg} / \mathrm{ml}$ kafein. Perlakuan kafein 2-4 $\mathrm{mg} / \mathrm{ml}$ menghasilkan energi yang mencukupi, sehingga adanya peningkatan hiperaktivasi untuk motilitas sperma sedangkan perlakuan kafein dengan level yang semakin meningkat $(6 \mathrm{mg} / \mathrm{ml})$ mengakibatkan kerusakan akrosom yang disebabkan karena konsentrasi $\mathrm{Ca}^{2+}$ yang meningkat mengakibatkan tidak terkendalinya hiperaktivasi sperma sehingga banyak lapisan luar akrosom yang terlepas atau rusak (Kito dan Ohta, 2005).

$$
\text { Kecepatan sperma kauda }
$$

epididymis sapi Bali memperlihatkan bahwa perlakuan kafein dengan level T4 $(88,00 \pm$ $12,03 \mu \mathrm{m} / \mathrm{s})$ dan T6 $(88,01 \pm 2,40 \mu \mathrm{m} / \mathrm{s})$ pada VCL berbeda nyata $(P>0,05)$ terhadap T0 $(85,06 \pm 1,40 \mu \mathrm{m} / \mathrm{s})$ dan T2 $(85,10 \pm 4,68$ $\mu \mathrm{m} / \mathrm{s}$ ), hal ini tentu saja karena semakin meningkat kadar kafein akan meningkatkan aktivasi kromosom sehingga pergerakan per menit akan semakin meningkat, namun amplitude (VAP) pada T2 $(46,41 \pm 1,52$ $\mu \mathrm{m} / \mathrm{s})$ berbeda nyata $(\mathrm{P}>0,05)$ dibandingkan T0 $(41,00 \pm 3,70 \mu \mathrm{m} / \mathrm{s})$, T4 $(42,01 \pm 2,21$ $\mu \mathrm{m} / \mathrm{s})$ dan T6 $(39,22 \pm 5,40 \mu \mathrm{m} / \mathrm{s})$. Hal ini dapat terjadi karena energi dalam sperma lebih stabil karena level kafein pas tidak berlebihan sehingga akan bergerak lebih lama.VAP akan berkorelasi dengan VSL dimana T2 $(34,47 \pm 3,23 \mu \mathrm{m} / \mathrm{s})$ berbeda nyata $(P>0,05)$ terhadap T0 $(29,25 \pm 3,24$ $\mu \mathrm{m} / \mathrm{s}), \mathrm{T} 4(31,02 \pm 1,40 \mu \mathrm{m} / \mathrm{s})$ dan T6 $(29,25$ $\pm 4,21 \mu \mathrm{m} / \mathrm{s}$ ), karena aplitudo stabil maka pergerkan sperma bergerak lurus akan lebih baik dibandingakan perlakuan kafein dengan konsentrasi tinggi. Jika dibandingkan dengan sperma ejakulat dengan penelitian yang dilakukan Sarastina dkk (2014), dengan nilai $\mathrm{VCL}(121,04 \pm 18,01 \mu \mathrm{m} / \mathrm{s})$, $\operatorname{VAP}(73,19 \pm 13,42 \mu \mathrm{m} / \mathrm{s})$ dan VSL $(60,39 \pm$ $14,65 \mu \mathrm{m} / \mathrm{s}$ ) sperma kauda epididymis lebih rendah, namun hasil kecepatan sperma kauda epididimis masih dalam nilai standar dapat membuahi sel telur secara in vitro. Kriteria spermatozoa hiperaktif dengan rerata curvelinier velocity $(\mathrm{VCL})>169 \mu \mathrm{m} / \mathrm{s}$, straighlinier velocity (VSL) $>30 \mu \mathrm{m} / \mathrm{s}$ dan spermatozoa dengan nilai VAP > 25 $\mu \mathrm{m} / \mathrm{s}$ (Royere, 1996 dalam Arifiantini, 2012).

\section{KESIMPULAN}

Hasil penelitian menunjukkan bahwa penambahan kafein $2-4 \mathrm{mg} / \mathrm{ml}$ pada pengencer tris kuning telur sperma kauda epididymis sapi Bali mampu meningkatkan motilitas sperma.

\section{DAFTAR PUSTAKA}

Arifiantini, I. 2012. Teknik Koleksi dan Evaluasi Semen Pada Hewan. IPB Press.

Garner, D. L and Hafez, E.S. E. 2000. Sperm and Seminal Plasma in Hafez, B and Hafez, E.S.E : Reproduction in Farm Animals. Lippincott Williams \& Wilkins. USA. Page; 97-105.

Gerhastuti, B.C. 2009. Pengaruh Pemberian Kopi Dosis Bertingkat Per Oral Selama 30 Hari Terhadap Gambaran Histologi Ginjal Tikus Wistar. Karya IImiah Fakultas Kedokteran. Universitas Diponegoro. Semarang.

Kito, S. and Ohta,Y. 2005. Medium Effects Capacitation and Sperm Penetration Trough The Zona Pellucida In Inbred BALB/c Sperma. J Zygote 13 (May), pp. 145-153. Cambridge University Press. New York.

Lamarine, R. J. 1998. Caffeine As An Ergogenic Aid. In Spiller: Caffeine. Health Research and studies Center and Sphera Foundation. Los Altos, California. CRC Prss.

Putranti, O.D. 2017. Pengaruh Penambahan Kafein Pada Sperma Kauda Epididimis Sapi Bali Pasca Thawing Terhadap Fertilitas Secara Fertilisasi In Vitro. Disertasi. Universitas Padjadjaran. Bandung.

Sarastina, T. Susilawati, G. Ciptadi. 2014. Analisa Beberapa Parameter Motilitas Sperma Pada Beberapa Bangsa Sapi Menggunakan Computer Assisted Semen Analysis (CASA). J. Ternak Tropika. 6 (2): 1-12.

Tambing, S. N. Toelihere, M. R. Yusuf dan I Ketut, S. 2000. Pengaruh Gliserol Dalam 
Pengencer Semen Beku Kambing Peranakan Etawah. J ITV. 5 (2): 1-8. Toelihere, M.R. 1993. Inseminasi Buatan Pada Ternak. Angkasa Bandung. Bandung.
Trihendradi, C. 2010. Step by Step Spss 18 Analisis Data Statistik. Andy offset. Yogyakarta. 